\title{
Causes of rejection of beef bulls in breeding soundness evaluation
}

\section{Silvio Renato Oliveira Menegassi ${ }^{1}$, Júlio Otávio Jardim Barcellos ${ }^{2}$, Vanessa Peripolli ${ }^{1}$, João Batista Souza Borges ${ }^{3}$, Mari Lourdes Bernardi ${ }^{4}$}

\footnotetext{
1 Programa de Pós-Graduação em Zootecnia, Faculdade de Agronomia, Universidade Federal do Rio Grande do Sul (UFRGS), Brasil.

2 Departamento de Zootecnia, Faculdade de Agronomia, UFRGS. Pesquisador CNPq.

${ }^{3}$ Departamento de Medicina Animal, Faculdade de Medicina Veterinária, UFRGS.

${ }^{4}$ Departamento de Zootecnia, Faculdade de Agronomia, UFRGS.
}

\begin{abstract}
The objective of this study was to analyze the rates of rejection in the different steps of the breeding soundness evaluation of beef bulls in the state of Rio Grande do Sul, Brazil. The breeding soundness of 22,113 young and mature bulls of 14 beef breeds, participating in the Program of Reproductive Evaluation (PARTO) was evaluated in the experiment. Data concerning to the causes of rejection in the four steps of the breeding soundness evaluation (general physical examination, genital tract examination, semen evaluation and sexual behavior assessment) were analyzed by the Chi-square test and univariate regression analysis. According to year, general physical examination, genital tract examination and semen evaluation determined the rejection of $0.9 \%$ to $2.5 \%, 5.1 \%$ to $7.7 \%, 1.8 \%$ to $5.3 \%$; and $4.2 \%$ to $6.7 \%$, 7.3 to $9.3 \%$, and $2.5 \%$ to $5.5 \%$ of young and mature bulls, respectively. Mature bulls presented higher chances of rejection than young bulls in the general physical examination in every year evaluated; as to the genital tract examination, their chances of rejection were higher in years I and II, but not in year III. In the semen evaluation, there was no difference between the ages assessed in any of the three years evaluated. Sexual behavior assessment accounted for the rejection of 1.9 to $6.0 \%$ of the young bulls and $2.9 \%$ to $3.9 \%$ of mature bulls, in accordance with the years evaluated; in years I and II, mature bulls presented higher rejection rates than young bulls. These results confirm the importance of performing all steps of the breeding soundness evaluation, including the sexual behavior assessment as a work routine, rather than an additional, optional stage of the evaluation, which should be carried out before the breeding season. The results indicate the relationship between bull age and rejection rate in the breeding soundness evaluation.
\end{abstract}

Key Words: behavior assessment, libido, mounting capacity, reproductive assessment

\section{Introduction}

Because $95 \%$ of cows and heifers considered apt for reproduction are subjected to natural service, it is fundamental to develop and apply reliable methods of evaluation of the reproductive potential of bulls in order to select the animals capable of transmitting desirable economic traits, such as fertility and precocity. High production costs and management failures account for unacceptable productivity rates in herds of small, medium and large producers. This emphasizes the need for the adoption of genetic, reproductive, nutritional, sanitary and managerial improvement in the breeding farms considered. The situation of cattle raising has become still worse with the marginalization process caused by the spread of crops in areas that were traditionally intended to cattle raising.

Menegassi et al. (2011) showed the bio-economical effect of breeding soundness evaluation: an increase of $31 \%$ in calf production, 13.8 calves/bull/year, an increase of $24 \mathrm{~kg}$ of calves/cow/year, and a cost-benefit ratio of US\$ 19.37, which raised the income of breeding farms.

Sereno et al. (2002) showed that it is possible to reduce the bull:cow ratio in the Brazilian Pantanal region without negatively influencing the fertility rate of the herd. Soundness analysis on the bull semen and the duration of the breeding season are fundamental for the establishment of the new bull:cow ratio and the incorporation of these recommendations in the extensive production system used in the Brazilian Pantanal may generate an economy of $28.88 \%$, if the bull:cow ratio changes from $1: 10$ to $1: 25$, or $35.55 \%$, if changed to a 1:40 ratio.

The complete breeding soundness evaluation is based on the assessment of all factors that contribute to the normal reproductive function of sires. It includes a general physical examination, examination of the external and internal genital tract, measurement of scrotal circumference, evaluation of the physical and morphological aspects of the semen, and sexual behavior assessment (Fonseca, 2009; CBRA, 1998). 
Rossi et al. (2009) evaluated yearling bulls and showed that sperm pathologies decrease as scrotal circumference increases. Scrotal circumference is easy to measure, and should be considered an important step of breeding soundness evaluation. Teeth wear and leg and feet problems are the main causes of culling of mature bulls. On the other hand, testicle hypoplasia is the main cause of culling of young bulls (Acuña \& Campero, 1997).

Because not all bulls accepted in general physical examination, genital tract examination, and semen evaluation are subjected to sexual behavior assessment, some bulls in breeding herds may not have the required mounting capacity. On the other hand, evaluating bulls only as to libido and mounting capacity may lead to inaccurate conclusions, since factors related to the previous experiences of bulls may affect the results of the test (Boyd et al., 1989). Lopes et al. (2009) considered that neither the andrological classification in scores nor the sexual behavior assessment were efficient to predict the breeding potential of Nellore bulls in terms of pregnancy rate at the end of the breeding season.

The objective of the present study was to analyze the rejection rates of beef bulls during the different steps of breeding soundness evaluation.

\section{Material and Methods}

The breeding soundness evaluation records of 6,874; 6,920; and 8,319 beef bulls evaluated from September to December (years I, II, and III, respectively) in the state of Rio Grande do Sul, Brazil, were analyzed, totaling 22,113 breeding soundness results. The data derive from the database of the Bull Reproductive Assessment Program (Programa de Avaliação Reprodutiva de Touros, PARTO) ${ }^{1}$, carried out by the National Rural Education Service of Rio Grande do Sul (Serviço Nacional de Aprendizagem Rural do Rio Grande do Sul, SENAR-RS).

Bulls from the following breeds were evaluated: Aberdeen Angus, Red Angus, Hereford, Polled Hereford, Devon, Shorthorn, Brangus, Braford, Montana, Santa Gertrudis, Charolais, Limousin, Nellore, and Tabapua. Twoyear-old bulls (young bulls) and three- to ten-year-old bulls (mature bulls) constituted two different groups; the latter were used on the breeding farm. Subsequently, the whole group was divided in one group of two- and three-year-old bulls, and another of older bulls for analyses of specific pathologies.
Breeding soundness evaluations were carried out on ranches in 54 counties of the state Rio Grande do Sul by veterinarians trained by the PARTO program, according to the norms of the Brazilian Association of Animal Breeding (CBRA, 1998). The evaluation included four steps:

Step 1 - general physical examination: eyes, teeth, body condition score and feet and legs.

Step 2 - genital tract examination: sheath, penis, scrotum, testicles, epididymides, scrotal circumference; and examination of the internal genital tract (vesicular glands and ampullae of the vasa deferentia) by rectal palpation. Scrotal circumference (SC) was measured by pulling the testicles to the bottom of the scrotum and placing a metal measuring tape around the widest circumference. The procedure was repeated immediately to check the measurement. The rejection criteria were SC lower than $30 \mathrm{~cm}$ in young bulls and lower than $32 \mathrm{~cm}$ in mature bulls of synthetic, continental, and British breeds, and SC lower than $28 \mathrm{~cm}$ in young bulls and lower than $30 \mathrm{~cm}$ in mature bulls of Zebu breeds. Bos taurus indicus bulls often have more elongated testicles than Bos taurus taurus, which causes a smaller scrotal circumference.

Step 3 - semen evaluation: sperm motility, vigor, masal motility and concentration. Semen was usually collected by electro-ejaculation or transrectal massage of the seminal vesicles and ampullae of the vasa deferentia, or, in some cases, by the use of artificial vagina. Whenever necessary, bulls were given a second chance to have their semen collected.

Step 4 - sexual behavior assessment: libido and mounting capacity tests. Libido was considered as the intention, drive or desire of the bull to mate, and mounting capacity as the completion of mating. These tests were carried out in a pen with a cow restrained in an artificial insemination collection chute. Bulls were placed together in an adjacent pen to be stimulated by the test of the other bulls. Bulls were tested in pairs for a maximum time of $10 \mathrm{~min}$. If one of the bulls passed before the 10-min interval elapsed, it was removed and replaced by another bull. The results were presence or absence of libido and/or mounting capacity. If a bull seemed too restless, lethargic, or aggressive, it was tested with a cow in estrus in a pen or paddock, giving it another opportunity to express or not its sexual behavior.

The sequence used for breeding soundness evaluation was first the general physical examination, followed by genital tract examination, semen evaluation, and behavioral assessment (libido and mounting capacity). When the bull

\footnotetext{
${ }^{1}$ The Bull Reproductive Assessment Program (Programa de Avaliação Reprodutiva de Touros - PARTO) aims at performing breeding soundness evaluation of bulls in beef cattle ranches in the state of Rio Grande do Sul before the breeding season. Further information can be obtained at the website of the System of the Federation of Agriculture of that state (Sistema da Federação da Agricultura do Estado do Rio Grande do Sul): http://www.paat.com.br
} 
was rejected in one of the tests, it was not subjected to the subsequent tests. Therefore, the results of the genital tract examination correspond only to the bulls which passed the general physical examination; the results of the semen evaluation include only bulls that passed both the general physical examination and in the genital tract examination. Consequently, the general rejection rate is cumulative for these three steps, and the number of bulls rejected in more than one step cannot be quantified.

Some farms did not have adequate infrastructure, and therefore not all bulls accepted in the three previous steps were sent to behavioral assessment, resulting in a lower number of bulls included in this step of breeding soundness evaluation.

In order to analyze the relationship between the binary variable (approved or rejected in the different steps of breeding soundness evaluation) and age classes (young and mature bulls), data were submitted to the Chi-Square test (PROC-FREQ) and univariate logistic regression analysis (PROC- LOGISTIC) using software package SAS (Statistical Analysis System, version 9.5).

\section{Results and Discussion}

The cumulative rejection rates observed in the present study are according to the expected rates, as in a bull population, 10 to $20 \%$ are expected to be rejected due to semen quantity and quality problems, physical defects that prevent mating, and/or absence of libido (Radostits et al., 1994) (Table 1).

In Argentina, Acuña \& Campero (1997), evaluating 8,739 young bulls ( 18 to 24 months of age) and 14,255 mature bulls (older than 36 months of age), also showed higher rejection rates in mature bulls when compared with young bulls (12.6\% versus 3.8\%). This finding is in accordance with the results of the present study (Table 1), which show that the general physical examination was the step of the breeding soundness evaluation that most contributed to rejection.

The rejection rates of mature bulls in the general physical examination were higher when compared with those of the young bulls in the three years evaluated, ranging from $3.2 \%$ to $4.8 \%$ on average (Table 1 ).

Beef cattle are produced in Rio Grande do Sul, Brazil, under grazing systems that are almost exclusively based on natural pastures, and the capacity of these pastures is seldom taken into account(Simeone \& Lobato, 1996). Therefore, seasonal variations in pasture availability generate nutritional deficiencies during winter, particularly energy deficiency, whose magnitude varies according to the year (Prates et al., 1979). The low body condition score obtained in the general physical evaluation was also responsible for bull rejection (Table 2), demonstrating the importance of adequate nutritional planning to allow bulls to face winter feed shortages in order to mate in the following breeding season.

The genital tract examination determined average rejection rates between $7.4 \%$ and $8.2 \%$, depending on the year (Table 1). Mature bulls presented higher chance of rejection in this examination in years I and II, but not in year III (Table 3).

Acuña \& Campero (1997) and Andrade et al. (1995) reported that the main causes of rejection of young bulls in the genital tract examination were small testicles. In this study, even though aspects related to testicles and epididymides were important, absence of libido and/or mounting capacity and semen pathologies were the main causes of rejection (Table 2).

Table 1 - Rejection percentage of young and mature bulls according to breeding soundness evaluation steps

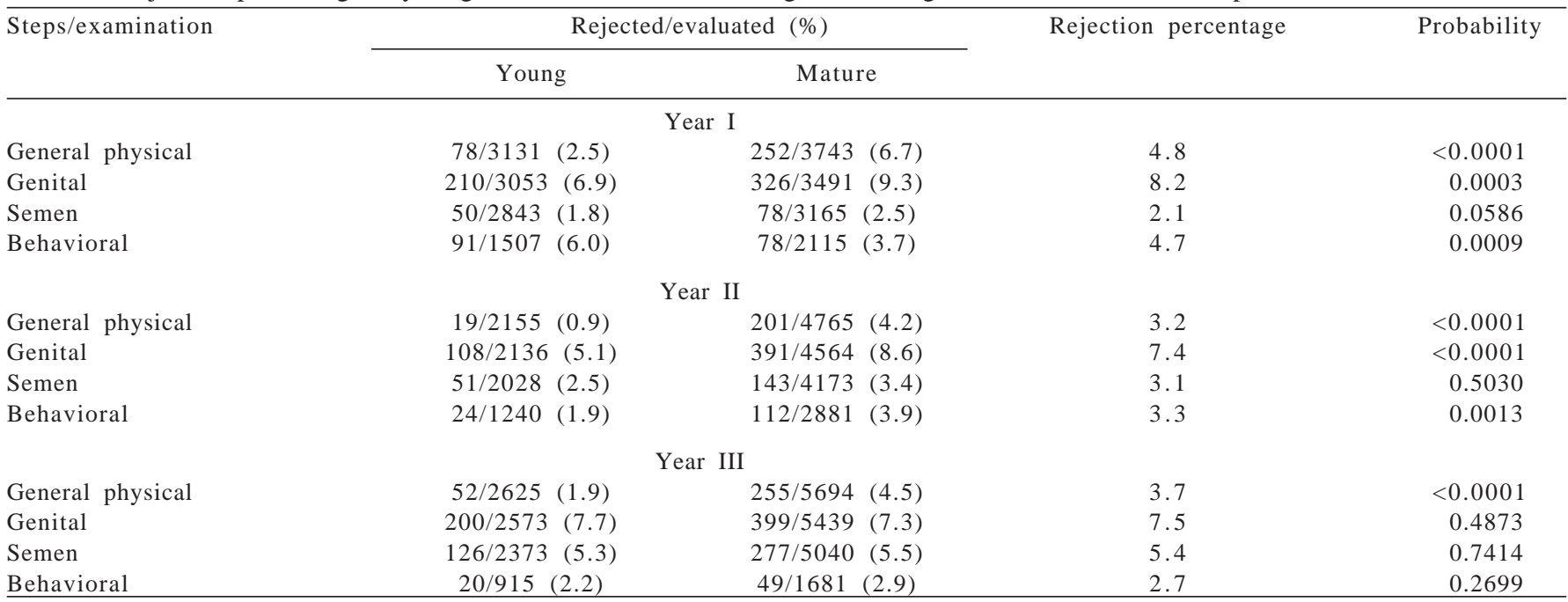


Table 2 - Main causes of rejection of the bulls evaluated

\begin{tabular}{|c|c|c|c|c|c|}
\hline \multirow[t]{2}{*}{ Causes } & \multicolumn{4}{|c|}{ Rejected (\%) } & \multirow[t]{2}{*}{ Total rejection } \\
\hline & $\mathrm{N}$ & Young & $\mathrm{N}$ & Mature & \\
\hline Libido and mounting capacity & 7,994 & $3.55 \mathrm{aB}$ & 6,140 & $5.24 \mathrm{bA}$ & 4.39 \\
\hline Semen & 17,354 & $3.54 \mathrm{aB}$ & 9,944 & $6.37 \mathrm{aA}$ & 4.95 \\
\hline Testicles and epididymides & 18,415 & $2.61 \mathrm{bcB}$ & 10,875 & $3.51 \mathrm{cA}$ & 3.06 \\
\hline Body condition/teeth & 19,068 & $2.28 \mathrm{cdB}$ & 11,632 & $4.15 \mathrm{cA}$ & 3.21 \\
\hline Vesicles and ampullae & 18,415 & $2.03 \mathrm{~dB}$ & 10,875 & $2.74 \mathrm{dA}$ & 2.38 \\
\hline Legs and feet & 19,068 & $0.70 \mathrm{eB}$ & 11,632 & $1.70 \mathrm{eA}$ & 1.20 \\
\hline Penis & 18,415 & $0.62 \mathrm{eB}$ & 10,875 & $1.19 \mathrm{fA}$ & 0.90 \\
\hline Sheath & 18,415 & $0.50 \mathrm{eB}$ & 10,875 & $1.19 \mathrm{fA}$ & 0.84 \\
\hline Total rejection & & 1.97 & & 3.26 & 2.61 \\
\hline
\end{tabular}

Different lowercase letters in the columns and capital letters in the rows indicate statistical difference (P<0.001).

Table 3 - Odds ratio of rejected mature bulls in relation to young bulls

\begin{tabular}{|c|c|c|c|}
\hline \multirow[t]{2}{*}{ Steps/examination } & \multicolumn{2}{|c|}{ Mature vs. young } & \multirow[t]{2}{*}{ Probability } \\
\hline & Estimated & Confidence interval $95 \%$ & \\
\hline \multicolumn{4}{|c|}{ Year I } \\
\hline Genital & 1.39 & $1.16-1.67$ & 0.0003 \\
\hline Semen & 1.41 & $0.99-2.03$ & 0.0598 \\
\hline Behavioral & 0.60 & $0.44-0.81$ & 0.0011 \\
\hline \multicolumn{4}{|c|}{ Year II } \\
\hline Genital & 1.75 & $1.41-2.19$ & $<0.0001$ \\
\hline Semen & 1.37 & $0.99-1.90$ & 0.5040 \\
\hline Behavioral & 2.05 & $1.31-3.20$ & 0.0016 \\
\hline \multicolumn{4}{|c|}{ Year III } \\
\hline General physical & 2.32 & $1.71-3.14$ & $<0.0001$ \\
\hline
\end{tabular}

Rejection rates due to semen evaluation problems ranged from $2.1 \%$ to $5.4 \%$, depending on the year evaluated (Table 1 ), and there was no odds ratio difference in rejection rates between mature and young bulls in all years evaluated (Table 3).

There are several studies of the effects of semen quality on the reproductive efficiency of breeding herds, but the interpretation of the results is controversial, once the prediction of the fertility potential of a semen sample rarely explains fertility differences between bulls (Hammerstedt, 1996; Dejarnette, 2005). Unlike the rejection rates in semen evaluation observed in the present study, Silva et al. (1981) reported $46 \%$ rejection in 1,902 two- to six-year-old bulls of various breeds, whereas Andrade et al. (1995) rejected 48\% of 33 two-year-old bulls due to semen defects. Semen quality problems were also the main cause of rejection of $11.6 \%$ and $13.7 \%$ of the bulls evaluated by Gottschall \& Mattos (1997) and Kennedy et al. (2002), respectively. It must be noted that the rejection rates due to low semen quality observed in the present study are related to bulls that were previously accepted in general physical and genital tract examinations. Bulls with epididymis, testicle, and seminal vesicle defects (Vale Filho, 1997) may present semen quality problems. This indicates that in the present study, the rejection rate in semen evaluation could have been higher if all bulls rejected in the genital tract examination had been subjected to semen evaluation.

Sexual behavior problems accounted for the rejection of $1.9 \%$ to $6.0 \%$ of young bulls and $2.9 \%$ to $3.9 \%$ of mature bulls (Table 1 ). The absence of libido and of serving capacity resulted in the rejection of $0.8 \%$ to $4.8 \%$ and $0.7 \%$ a $2.4 \%$, depending on bull age and year evaluated (Table 4), demonstrating the importance of behavioral assessment when evaluating breeding soundness. In this step, bull age seemed to have a less consistent effect, as shown by the higher rejection rate due to absence of libido in young bulls in year I, and in mature bulls in year III. As to mounting capacity, mature bulls presented higher rejection rate, but only in year II (Table 4).

The system adopted in beef cattle production alters the social structure considerably, because the lots are composed 
of animals of the same sex, age and physiologic state. This alters many of the bovine social characteristics. To guarantee the reproductive efficiency of the herd, some care can be taken in all the sub-processes involved in bovine reproduction, considering the knowledge of its social structure and how they relate with individuals of their species and of different species, besides men (Costa \& Silva, 2007).

Although the behavioral assessment of bulls is not always carried out, rejection rates of $42.5 \%$ in a total rate of $20.7 \%$ have been reported due to absence of libido and mounting capacity in mature bulls (Blockey, 1984).

In a study evaluating 7,021 young bulls and 5,669 mature bulls, Acuña \& Campero (1997) found 5.18\% and $6.43 \%$ of rejections, respectively, concerning libido evaluation and mounting capacity. This shows the importance of this step in the reproductive evaluation of bulls.

Several factors may affect the expression of libido (Petherick, 2005), and test on pasture conditions may influence the results (Chenoweth, 1994; Coulter \& Kozub, 1989).

During the test in the pen, the classification scores increased as the testing time increased, but no bull accomplished complete service in the first 10 minutes of the test. A very good bull obtained $84.80 \%$ for pregnancy rate, but other questionable bulls obtained 86.67 and $96.55 \%$ at the end of the breeding season(Oliveira et al., 2007). Although libido and mounting capacity tests may not be sufficient to precisely determine potential pregnancy rates (Parkinson, 2004), it is possible to assert that the chances of obtaining good pregnancy rates are higher when bulls pass the three first steps of breeding soundness evaluation and show both presence of libido and mounting capacity.

The higher rejection rate of mature bulls found in the present study is consistent with results previously found (Blockey, 1984; Acuña \& Campero, 1997; Gottshall \& Mattos, 1997; Menegassi et al., 2008).

The behavioral assessment, as a step of the breeding soundness evaluation, showed to be important for proper reproductive evaluation of bulls. The rejection rates in the behavioral assessment of bulls demonstrated that this step should become mandatory, rather than being just a complementary test during breeding soundness evaluation in bulls (Menegassi et al., 2011).

Table 4 - Rejection of young and mature bulls in the sexual behavior assessment

\begin{tabular}{|c|c|c|c|c|}
\hline \multirow[b]{2}{*}{ Causes } & \multicolumn{2}{|c|}{ Rejected/evaluated (\%) } & \multirow[t]{2}{*}{ Total rejection } & \multirow[t]{2}{*}{ Probability } \\
\hline & Young & Mature & & \\
\hline \multicolumn{5}{|c|}{ Year I } \\
\hline Libido & $75 / 1507(4.8)$ & $44 / 2115(2.1)$ & 3.3 & $<0.0001$ \\
\hline Serving capacity & $16 / 1432(1.1)$ & $34 / 2071$ (1.6) & 1.4 & 0.1983 \\
\hline \multicolumn{5}{|c|}{ Year II } \\
\hline Libido & $10 / 1240(0.8)$ & $43 / 2881(1.5)$ & 1.3 & 0.07030 \\
\hline Serving capacity & $14 / 1230$ & $69 / 2838(2.4)$ & 2.0 & 0.0074 \\
\hline \multicolumn{5}{|c|}{ Year III } \\
\hline Libido & 9/915 (1.0) & $34 / 1681$ (2.0) & 1.7 & 0.0475 \\
\hline Serving capacity & 9/906 (1.0) & $11 / 1647(0.7)$ & 0.8 & 0.3721 \\
\hline
\end{tabular}

\section{Conclusions}

Performing all steps of the breeding soundness evaluation is essential for the correct assessment of bulls. Mature bulls do not always present higher rejection rates than young bulls. Despite the success in the previous steps of breeding soundness evaluation, the rejection in the behavioral assessment indicates that this step should become a norm, rather than a complementary test. It is suggested that the behavioral assessment be adopted as a work routine for bull reproductive evaluation.

\section{References}

ACUÑA, C.M.; CAMPERO, C.M. Problemas reprodutivos, clínicos e a prova de capacidade de serviço em 22.994 touros de raças de carne na Argentina. In: JORNADAS URUGUAIAS DE BUIATRIA E CONGRESSO LATINO DE BUIATRIA, 25. Paysandu. Proceedings... Paysandu: Sociedade Latinoamericana de Buiatria, 1997. p.6-8.

ANDRADE, V.J.; VALE FILHO, V.R.; BERGMANN, J.A. et al. Causas de Eliminação de touros Nelores de dois anos de idade, submetidos a avaliação andrológica, para uso em estação de monta. In: CONGRESSO BRASILEIRO DE REPRODUÇÃO ANIMAL, 11., 1995, Belo Horizonte. Anais... Belo Horizonte: Colégio Brasileiro de Reprodução Animal, 1995. p.283. 
BLOCKEY, M.A.B. Using bull fertility to increase herd fertility. In: HUNGERFORD, T.G. (Ed.) Beef cattle production. Australia: University of Sydney, 1984. p.509-527.

BOYD, G.W.; LUNSTRA, D.D.; CORAH, L.R. Serving capacity of crossbred yearling beef bulls. I. Single-sire mating behavior and fertility during average and heavy mating loads at pasture. Journal of Animal Science, v.67, p.60-71, 1989.

CHENOWETH, P.J. Bull behavior, sex-drive and management. In: FIELDS, M.J.; SAND, R.S. (Eds.) Factors affecting calf crop. CRC Press, 1994. p.319-330.

COLÉGIO BRASILEIRO DE REPRODUÇÃO ANIMAL - CBRA. Manual para exame andrológico e avaliação de sêmen animal. 2.ed. Belo Horizonte: CBRA, 1998. 49p.

COSTA E SILVA, E.V. Comportamento e eficiência reprodutiva. Revista Brasileira de Reprodução Animal, v.31, p.177-182, 2007.

COULTER, G.H.; KOZUB, G.C. Efficacy of methods used to test fertility of beef bulls used for multiple-sire breeding under range conditions. Journal of Animal Science, v.67, p.1757-1766, 1989.

DEJARNETTE, J.M. The Effect of semen quality on reproductive efficiency. Veterinary Clinics North America: Food Animal Practice, v.21, p.409-418, 2005.

FONSECA, V.O. Avaliação reprodutiva de touros para a monta a campo: análise crítica. Revista Brasileira de Reprodução Animal, v.6, p.36-41, 2009

GOTTSCHALL, C.S.; MATTOS, R.C. Achados de exames andrológicos em touros de corte Bos taurus e Bos indicus. Revista Brasileira de Reprodução Animal, v.21, p.25-28, 1997.

HAMMERSTEDT, R.H. Evaluation of sperm quality: Identification of the sub fertile male and courses of action. Animal Reproduction Science, v.42, p.77-87, 1996.

HOLROYD, G.R.; FORDYCE, G.; BERTRAM, J.D. et al. Uso y evaluación de toros bos indicus em condiciones de manejo extensivas y semi-intensivas: Um resumen de las actividades en Norte de Austrália. In: SIMPOSIO INTERnACIONAL DE REPRODUCCIÓn ANIMAL, 4., 2001, Córdoba. Anais... Córdoba, 2001. p.9-24.

KENNEDY, S.P.; SPITZER, J.C.; HOPKINS, F.M. et al. Breeding soundness evaluations of 3648 yearling beef bulls using the 1993 Society for Theriogenology guidelines. Theriogenology, v.58, p.947-961, 2002.

LOPES, F.G.; GUIMARÃES, J.D.; COSTA, E.P. et al. Avaliação Andrológica por pontos e comportamento sexual em touros da raça Nelore. Revista Brasileira de Zootecnia, v.25, p.1018-1025, 2009.
MENEGASSI, S.R.O.; CANOZZI, M.E.A.; TEIXEIRA, J.L. et al. Causas Físicas de Descartes de Touros no Rio Grande do Sul. In: CONGRESSO BRASILEIRO DE MEDICINA VETERINÁRIA, 25., 2008, Gramado. Anais... Gramado: Sociedade de Veterinária do Rio Grande do Sul. [2008]. (CD-ROM).

MENEGASSI, S.R.O.; BARCELLOS, J.O.J.; PERIPOLLI, V. et al Behavioral assessment during breeding soundness evaluation of beef bulls in Rio Grande do Sul. Animal Reproduction, v.8, p.77-80, 2011.

OLIVEIRA, C.B.; GUIMARÃES, J.D.; COSTA, E.P. et al. Avaliação do comportamento sexual em touros Nelore: comparação entre os testes da libido em curral e do comportamento sexual a campo. Revista Brasileira de Zootecnia, v.36, p.32-42, 2007.

PARKINSON, T.J. Evaluation of fertility and infertility in natural service bulls. Veterinary Journal, v.168, p.215-229, 2004.

PETHERICK, J.C. A Review of some factors affecting the expression of libido in beef cattle and individual bull and herd fertility. Applied Animal Behavior Science, v.90, p.185-205, 2005.

PRATES, E.R.; LEBOUTE, E.M.; MORAES, C.M.M. Avaliação da forragem disponível das pastagens do Rio Grande do Sul. In: REUNIÃO ANUAL DA SOCIEDADE BRASILEIRA DE ZOOTECNIA, 16., Curitiba. Anais... Curitiba: Sociedade Brasileira de Zootecnia, 1979. p.272.

RADOstits, O.M.; LESLIE, K.E.; FETROW, J. Herd health: food animal production medicine. 2.ed. Philadelphia: WB. Saunders, 1994.

ROSSI, R.O.D.S.; BARRETO, FILHO. J.B.; CARVALHO, P.H.A. et al. Características andrológicas e do sêmen de touros do composto Red Norte (Nelore Tabapuã x Red Angus x Senepol). Arquivo Brasileiro de Medicina Veterinária e Zootecnia, v.61, p.1297-1801, 2009.

SERENO, J.R.B.; COSTA E SILVA, E.V.; MORES, C.M. Redução da proporção touro vaca no Pantanal brasileiro. Pesquisa Agropecuária Brasileira, v.37, p.1811-1817, 2002.

SILVA, J.F.; PEREIRA, D.A.S.; OLIVEIRA, J.F.C. et al. Avaliação da Fertilidade Potencial de Touros. In: SIMPÓSIO NACIONAL DE REPRODUÇÃO ANIMAL, 9., Belo Horizonte. Anais... Belo Horizonte: Colégio Brasileiro de Reprodução Animal, 1981. p.06.

SIMEONE, A.; LOBATO, J.F.P. Efeito da lotação animal em campo nativo e do controle da amamentação no comportamento reprodutivo das vacas de corte primíparas. Revista Brasileira de Zootecnia, v.25, p.1216-1227, 1996.

UNIVERSIDADE FEDERAL DO RIO GRANDE DO SUL - UFRGS Diagnóstico de sistemas de produção de bovinocultura de corte do Estado do Rio Grande do Sul. Relatório 2005. Porto Alegre, 2005. 265p.

VALE FILHO, V.R. Andrologia no touro: avaliação genital, exame do sêmen e classificação por pontos. Revista Brasileira de Reprodução Animal, v.21, p.7-13, 1997. 